SJ Quinney College of Law, University of Utah Utah Law Digital Commons

Utah Law Faculty Scholarship

Utah Law Scholarship

$8-2018$

\title{
Taking it to the Limit: Shifting U.S. Antitrust Policy Toward Standards Development
}

Jorge L. Contreras

S.J. Quinney College of Law, University of Utah, jorge.contreras@law.utah.edu

Follow this and additional works at: https://dc.law.utah.edu/scholarship

Part of the Intellectual Property Law Commons

\section{Recommended Citation}

Contreras, Jorge L., "Taking it to the Limit: Shifting U.S. Antitrust Policy Toward Standards Development" (2018). Utah Law Faculty Scholarship. 116.

https://dc.law.utah.edu/scholarship/116

This Article is brought to you for free and open access by the Utah Law Scholarship at Utah Law Digital Commons. It has been accepted for inclusion in Utah Law Faculty Scholarship by an authorized administrator of Utah Law Digital Commons. For more information, please contact valeri.craigle@law.utah.edu. 


\title{
TAKING IT TO THE LIMIT: Shifting U.S. Antitrust Policy Toward Standards DeVelopment
}

\author{
Jorge L. Contreras ${ }^{1}$ \\ Draft for Comment: July 23, 2018
}

You can spend all your time making money, You can spend all your love making time

$\cdots$

So put me on a highway and show me a sign And take it to the limit one more time.

-- The Eagles, "Take it to the Limit" $(1975)^{2}$

In November 2017, U.S. Assistant Attorney General Makan Delrahim, President Trump's newlyappointed chief of the Department of Justice (DOJ) Antitrust Division, gave a speech at University of Southern California provocatively entitled "Take it to the Limit: Respecting Innovation Incentives in the Application of Antitrust Law". ${ }^{3}$ In this speech, Mr. Delrahim announced a new DOJ policy approach to the antitrust analysis of collaborative standard setting and standards-development organizations (SDOs) -- the trade associations and other groups in which industry participants cooperate to develop interoperability standards such as Wi-Fi, Bluetooth, 4G and 5G, USB and the like. ${ }^{4}$ He explained that the DOJ had "strayed too far" in its focus on single firm conduct concerning standards, particularly the assertion of patents essential to the implementation of standards in technology products ("standards-essential patents" or "SEPs"), and that antitrust authorities should be more concerned with potential collusion by competitors within SDOs (i.e., an apparent shift in doctrinal focus from unilateral conduct under Section 2 of the Sherman Act to concerted action under Section 1 of the Sherman Act). ${ }^{5}$ One commentator described the DOJ policy shift announced by Mr. Delrahim as "a 180 degree turn"

\footnotetext{
${ }^{1}$ University of Utah S.J. Quinney College of Law. The author has been engaged as an expert in cases involving standards-development on behalf of both patent holders and product manufacturers, and served for twenty years as legal counsel to the Internet Engineering Task Force (IETF), a standards-development organization.

${ }^{2}$ Take it to the Limit, written by Glenn Frey, Don Henley, Randy Meisner (the Eagles); Lyrics copyright 1975, Cass County Music, Wisteria Music, Privet Music, Warner/Chappell Music, Inc, Universal Music Publishing Group, Red Cloud Music.

${ }^{3}$ Asst. Atty. Gen. Antitrust Div., U.S. Dept. Justice, Makan Delrahim, Take it to the Limit: Respecting Innovation Incentives in the Application of Antitrust Law - Remarks as Prepared for Delivery at the USC Gould School of Law, Nov. 10, 2017, https://www.justice.gov/opa/speech/file/1010746/download. For an annotated version of Mr. Delrahim's November 2017 and subsequent speeches discussed in this article, as well as responses submitted to those speeches, see Mark Patterson, The Patent-Antitrust Debate Annotated, PatentlyO blog, Jul. 23, 2018, https://patentlyo.com/patent/2018/07/patent-antitrust-anotated.html.

${ }^{4}$ Because SDOs are comprised largely of competitors that cooperate on these technical activities, technical standardization can give rise to antitrust concerns. See, generally, The CAmbridge HandBook of TeChNiCAL StandardiZATion Law: Competition, Antitrust, And PAtents (Jorge L. Contreras, ed., 2017).

${ }^{5} 15$ U.S.C. $\S \S 1,2$.
} 
on SEP issues. ${ }^{6}$ The new policy also seems to put the enforcement priorities of the Antitrust Division at odds with those of the other principal U.S. antitrust enforcement agency, the Federal Trade Commission (FTC).

The contrast drawn by Mr. Delrahim between unilateral and concerted conduct is exemplified by two recent cases at the intersection of antitrust law and standardization: on the unilateral side, the actions brought by competition agencies around the world, including the FTC, against Qualcomm, Inc. for a range of alleged anticompetitive practices concerning the sale of wireless communication chips and patents covering wireless telecom standards ${ }^{7}$ and, on the concerted action side, a set of 2015 amendments to the IEEE's patent policy that sought to clarify aspects of its members' obligation to license standards-essential patents (SEPs) on terms that are "reasonable and non-discriminatory" (RAND). ${ }^{8}$ Though the IEEE obtained a favorable business review letter from the DOJ prior to adopting these amendments, ${ }^{9}$ critics argue that the DOJ turned a blind eye to potential collusion by IEEE members that pushed through the amendments to disadvantage SEP holders. ${ }^{10}$

\section{DOJ versus FTC: Roles in standardization policy}

The U.S. is unusual among developed economies in that it has not one, but two, federal agencies that enforce the antitrust laws and fashion antitrust policy. The Department of Justice Antitrust Division was established in 1933 and is today one of eight operational divisions of the DOJ that is led by a Presidentially-nominated Assistant Attorney General. Among other things, the Antitrust Division is authorized to enforce the Sherman Antitrust Act. The Division also issues non-binding business review letters to applicants regarding the Division's current enforcement intentions regarding proposed transactions. ${ }^{11}$ As discussed below, numerous business review letters have been issued with respect to standardization organizations.

The Federal Trade Commission is an independent federal agency established by Congress in 1914 under the FTC Act. ${ }^{12}$ It consists of five Presidentially-nominated Commissioners who serve seven-year terms and no three of whom can be of the same political party. The FTC's Bureau of Competition is charged, among other things, with policing "unfair methods of competition" under Section 5(a) of the FTC Act. ${ }^{13}$ Unfair methods of competition include any conduct that would be in violation of the Sherman Antitrust Act, as well as other actions that

\footnotetext{
${ }^{6}$ Richard Lloyd, US Antitrust Chief Antitrust Speech "Marks a Major Pro-IP and Pro-Innovator Shift in DOJ Policy”, IAM BLOG, Nov. 16, 2017.

${ }^{7}$ Fed. Trade Comm'n v. Qualcomm, Inc., Case 5:17-cv-00220 (N.D. Cal. Filed Jan. 17, 2017).

${ }^{8}$ IEEE Standards Assn., IEEE Standards Board Bylaws (2015), Sec. 6.

${ }^{9}$ Business Review Letter from Renata B. Hesse, Acting Assistant Attorney General to Michael A. Lindsay dated February 2, 2015 [hereinafter IEEE 2015 Letter].

${ }^{10}$ See, e.g., J. Gregory Sidak, The Antitrust Division's Devaluation of Standard-Essential Patents, 104 GEO. L.J. ONLINE 48, 67-72 (2015).

${ }^{11}$ U.S. Dep't of Justice, Business Review Procedure, 28 C.F.R. $\S 50.6$.

1215 U.S.C. $\S \S 41-58$.

1315 U.S.C. $\S 45(\mathrm{a})$.
} 
"contravene the spirit of the antitrust laws."14 The FTC's scope of enforcement authority thus extends beyond the Sherman Act, though the precise contours of this authority are somewhat unclear. ${ }^{15}$

In many instances, the two agencies cooperate. In the area of intellectual property and antitrust law, the DOJ and FTC have produced valuable joint guidelines outlining their common views regarding the analysis of different types of joint and unilateral conduct. ${ }^{16}$ However, in the area of standardization, the DOJ and FTC have taken on different roles. Specifically, the DOJ, through its business review letter process, has served a valuable vetting function for SDOs and other organizations considering novel approaches to standardization or the treatment of SEPs. Table 1 lists the principal DOJ business review letters pertaining to technical standards.

\section{Table 1}

DOJ Standards-Related Business Review Letters ${ }^{17}$
\begin{tabular}{|c|c|}
\hline Year & Standard/SDO \\
\hline 1997 & MPEG-2 \\
\hline 1998 & 3C DVD \\
\hline 1999 & 6 C DVD \\
\hline 2002 & 3 GPP \\
\hline 2006 & VITA \\
\hline 2007 & IEEE (1) \\
\hline 2008 & RFID \\
\hline 2013 & IPXI \\
\hline 2015 & IEEE (2) \\
\hline
\end{tabular}

Unlike the DOJ, the FTC does not have an advance review process. However, the FTC has taken a far more active role than the DOJ in bringing enforcement actions against parties involved in standardization. Table 2 lists the principal enforcement actions relating to technical standards brought by the FTC since the 1990s.

Table 2

FTC Standards-Related Enforcement Actions

\begin{tabular}{|c|c|c|}
\hline Year Resolved & Defendant(s) & Outcome \\
\hline 1996 & Dell & Consent decree \\
\hline 2003 & Unocal & Consent decree \\
\hline 2008 & N-Data & Consent decree \\
\hline 2008 & Rambus & Reversed (DC Circuit) \\
\hline 2012 & Bosch & Consent decree \\
\hline
\end{tabular}

\footnotetext{
${ }^{14}$ Fed. Trade Comm'n, Statement of Enforcement Principles Regarding “Unfair Methods of Competition” Under Section 5 of the FTC Act (Aug. 13, 2015).

${ }^{15}$ See, e.g., Fed. Trade Comm'n, Dissenting Statement of Commissioner Maureen K. Ohlhausen - FTC Act Section 5 Policy Statement (Aug. 13, 2015).

${ }^{16}$ E.g., U.S. Dep't of Justice \& Fed. Trade Comm'n, Antitrust Enforcement and Intellectual Property Rights: Promoting Innovation and Competition (2007) [DOJ-FTC Antitrust and IPR]; U.S. Dep't of Justice \& Fed. Trade Comm'n, Antitrust Guidelines for the Licensing of Intellectual Property (2017).

${ }^{17}$ See U.S. Dept. Justice Antitrust Div., Business Review Letters and Request Letters, https://www.justice.gov/atr/business-review-letters-and-request-letters.
} 


\begin{tabular}{|c|c|c|}
\hline 2013 & Google/Motorola & Consent decree \\
\hline Filed 2017 & Qualcomm & Still Pending \\
\hline
\end{tabular}

The differences in approach to enforcement taken by the FTC and DOJ in the standardization area are notable. Of course, the FTC's lack of a statutory mechanism for providing formal prospective guidance to petitioners akin to the DOJ's business review procedure explains why this approach has been utilized exclusively by the DOJ. However, the DOJ's lack of formal litigation/enforcement is interesting, not only because the DOJ, and the Antitrust Division in particular, actively litigates cases in other areas (e.g., merger control ${ }^{18}$ ), but because throughout the twentieth century the DOJ was the agency most intent on condemning anticompetitive patent arrangements, with the FTC playing only a negligible role in the area. ${ }^{19}$ The agencies' roles reversed, however, beginning in the early 2000s, with the DOJ bringing no such litigation after its massive case against Microsoft, and the FTC initiating all of the cases listed in Table 2.

Why this turnabout? One possibility is suggested by the trajectory of judicial Sherman Act decisions over the 2000s. During that period, courts progressively narrowed the scope of actionable unilateral conduct under Section $2 .{ }^{20}$ As a result, the DOJ may have found a dwindling number of suitable cases involving patent-related conduct. The FTC, however, also had at its disposal Section 5 of the FTC Act and its broader definition of "unfair methods of competition". Section 5 claims played a major role in most of the FTC enforcement cases listed in Table 2. Thus, the FTC's current role as the primary antitrust enforcer in the area of standard setting may be attributable to its unique statutory mandate under the FTC Act, a mandate that is not shared by the DOJ.

\section{A New Attitude Toward Hold-up}

Until last year, one of the principal concerns shared by the FTC and DOJ in the area of standard setting was the threat of patent hold-up. Though its definition is the subject of some debate, ${ }^{21}$ hold-up in this context is often understood to be the "[t]he ability of a holder of [a] SEP to demand more than the value of its patented technology." 22 In their joint 2007 report on antitrust and IP, the DOJ and FTC acknowledged the potential competitive harm that could flow from patent hold-up. ${ }^{23}$ During the early 2010s, leaders of the DOJ Antitrust Division repeatedly emphasized the importance of policing and limiting hold-up behavior. One DOJ official publicly

\footnotetext{
${ }^{18}$ See, e.g., United States v. AT\&T Inc., Case No. 1:17cv-02511-RJL (D.D.C. Jun. 12, 2018).

${ }^{19}$ See Jorge L. Contreras, A Brief History of FRAND: Analyzing Current Debates in Standard Setting and Antitrust through a Historical Lens, 80 ANTITRUST L.J. 39, Appendix B (2015) (from 1942-2002, the DOJ brought 108 cases for anticompetitive practices involving patents, while the FTC brought only six (including In re. Dell - not listed)). ${ }^{20}$ See William E. Kovacic \& Marc Winerman, Competition Policy and the Application of Section 5 of the Federal Trade Commission Act, 76 AnTiTRUst L.J. 929, 929 n.2 (2010) (citing Pac. Bell Tel. Co. v. linkLine Commc'ns, Inc., 129 S. Ct. 1109 (2009), Weyerhaeuser Co. v. Ross-Simmons Hardwood Lumber Co., 549 U.S. 312 (2007); and Verizon Commc'ns Inc. v. Law Offices of Curtis v. Trinko, LLP, 540 U.S. 398 (2004)).

${ }^{21}$ See Jorge L. Contreras, Much Ado About Holdup, __ U. Ill. L. Rev. _ (forthcoming 2019).

${ }^{22}$ Microsoft Corp. v. Motorola, Inc., Findings of Fact and Conclusions of Law, No. C10-1823JLR, 2013 WL 2111217 (W.D. Wash. Apr. 25, 2013). See also Ericsson Inc. v. D-Link Sys., 773 F.3d 1201, 1209 (Fed. Cir. 2014 ) (holdup occurs "when the holder of a SEP demands excessive royalties after companies are locked into using a standard.")

${ }^{23}$ See DOJ-FTC Antitrust and IPR, supra note 16, at 33-56.
} 
stated that hold-up by SEP owners was "at the forefront of many of the Antitrust Division's intellectual property (IP) related enforcement and advocacy efforts." 24

Concern over the potential anticompetitive effects of patent hold-up motivated many of the FTC's enforcement actions discussed above, including its current litigation against Qualcomm. In the Qualcomm case, the FTC alleges, among other things, that Qualcomm violated the law by linking the sale of its baseband chips to SEP licenses, that it refused to license rival chipmakers under its SEPs, and that an exclusive arrangement with a major customer was intended to foreclose competition and market entry. ${ }^{25}$ As recently as March 2018, a Commissioner of the FTC reaffirmed the agency's concern with anticompetitive hold-up conduct. ${ }^{26}$

But in November 2017, AAG Delrahim effectively reversed the DOJ's position regarding patent hold-up and unilateral conduct in standard-setting. He first expressed skepticism regarding the very existence of hold-up, referring repeatedly to the "so-called holdup problem" so as to emphasize its "shaky empirical foundations". ${ }^{27} \mathrm{He}$ then expressed concern over agency attempts to police hold-up, attacking them as "anathema to the policies underlying the intellectual property system," "a serious threat to the innovative process," and "a misuse of antitrust or competition law." 28

\section{A New Emphasis on Concerted Action}

In place of unilateral conduct as a fruitful subject of antitrust scrutiny, AAG Delrahim offered an increased focus on concerted action. In particular, he observes that "[g]iven the incentives participants in SSOs face to bend licensing negotiations to their benefit, there is a risk that members of standard setting bodies could engage in collusive, anticompetitive behavior." ${ }^{29}$ He specifically points out that the amendment of SDO policies in a manner that is unfavorable to SEP holders may warrant particular scrutiny, stating that:

The Antitrust Division will ... be skeptical of rules that SSOs impose that appear designed specifically to shift bargaining leverage from IP creators to implementers, or vice versa. SSO rules purporting to clarify the meaning of "reasonable and non-

\footnotetext{
${ }^{24}$ Fiona Scott Morton, Deputy Asst. Atty. Gen. for Econ. Anal., Antitrust Div., U.S. Dept. Justice, The Role of Standards in the Current Patent Wars at 2 (Dec. 5, 2012). See also Renata Hesse, Deputy Assistant Atty. Gen., Antitrust Div., U.S. Dep't of Justice, Remarks at the ITU-T Patent Roundtable: Six “Small” Proposals for SSOs Before Lunch, at 4-6 (Oct. 10, 2012) (discussing hold-up).

${ }^{25}$ Fed. Trade Comm'n v. Qualcomm, Inc., Case 5:17-cv-00220 (N.D. Cal. Filed Jan. 17, 2017). Commissioner Maureen Ohlhausen filed a dissenting statement objecting to the initiation of the suit. Dissenting Statement of Commissioner Maureen K. Ohlhausen in the Matter of Qualcomm, Inc. (Jan. 17, 2017) (Commissioner Ohlhausen has announced her retirement from the FTC).

${ }^{26}$ Commissioner Terrell McSweeny, Holding the Line on Patent Holdup: Why Antitrust Enforcement Matters (Mar. 21, 2018) (Commissioner McSweeny retired from the FTC shortly after this statement was released).

${ }^{27}$ Delrahim, Take it to the Limit, supra note 3, at 4 n.6. Mr. Delrahim and a group of commentators supporting his position refer to a number of studies purporting to show a lack of empirical evidence of systemic patent hold-up. See Letter from Jonathan Barnett et al. to Asst. Atty. Gen. Makan Delrahim, Feb. 13, 2018 (citing literature). The author has previously questioned the fundamental premises and assumptions supporting these conclusions. Contreras, Hold-Up, supra note 21.

${ }^{28}$ Delrahim, Take it to the Limit, supra note 3, at 5-7.

${ }^{29} \mathrm{Id}$. at 10.
} 
discriminatory" that skew the bargain in the direction of implementers warrant a close look to determine whether they are the product of collusive behavior within the $\mathrm{SSO}^{30}$

These comments appear to be directed at IEEE's 2015 policy amendments, which clearly purport to clarify the meaning of 'reasonable and nondiscriminatory'. The IEEE amendments also limit the ability of a SEP holder to seek injunctive relief against a "willing" potential licensee. When asked during a 2018 interview whether the DOJ intends to rescind the favorable business review letter that it issued to IEEE in 2015, as urged by some commentators, ${ }^{31} \mathrm{Mr}$. Delrahim responded:

I have lately expressed concerns that promulgating rules that limit the ability of patent holders to seek injunctions risks undermining incentives to innovate. I have also said that such rules could potentially violate the antitrust laws where the limitation is imposed by a group of implementers with market power and has the effect of pushing royalty rates down. Nothing in the IEEE letter prevents the Division from acting where newly uncovered evidence discloses that those circumstances are present". ${ }^{32}$

The DOJ's intentions with respect to IEEE thus remain unclear. While it would ordinarily be unthinkable for the DOJ to prosecute activity approved under a recent business review letter, the Trump DOJ has embarked on an aggressive campaign of affirmatively revoking guidance documents that were issued during prior Administrations. ${ }^{33} \mathrm{~A}$ reversal of course as to IEEE would thus not be out of character for today's DOJ. But even if the DOJ declines to bring an action against IEEE with regard to its 2015 policy change, Mr. Delrahim's latest comments send a clear warning to any other SDOs that may be considering an amendment to their patent policies along similar lines.

\section{Is it All Just Politics?}

Observing the abrupt change of policy direction at the DOJ Antitrust Division, one may wonder whether it was politically motivated. Former International Trade Commissioner F. Scott Kieff and economist Anne Layne Farrar have studied the susceptibility of the U.S. DOJ and FTC to political and commercial pressures, coining the term "government hold-up" to describe attempts by government actors to influence policy in response to such political and commercial pressures. ${ }^{34}$ Likewise, economist J. Gregory Sidak has criticized the political nature of the DOJ

\footnotetext{
${ }^{30} \mathrm{Id}$. at 11 .

${ }^{31}$ See, e.g., Koren W. Wong-Ervin, Righting the Course: What the DOJ Should do About the IEEE Business Review Letter, CPI NorTh AMERICA COlumn 1, 3, Aug. 2017 ("One possible solution is for the DOJ's new leadership to announce its intention to investigate the process concerns with the amendments to the IEEE's IPR Policy. The DOJ should also renounce the sections of the prior administration's IEEE BRL that endorse certain policies (namely essentially prohibiting injunctive relief, requiring licensing at the component level, and recommending valuation based on the "smallest saleable patent practicing unit")").

${ }^{32}$ CPI Talks with Makan Delrahim, an Interview by Judge Douglas Ginsburg, CPI ANTITRUST Chron., Jun. 2018.

${ }^{33}$ See Matthew Perlman, DOJ Weeding out 'Legacy' Antitrust Judgments, Law360, Apr. 25, 2018; Charlie Savage, Justice Dept. Revokes 25 Legal Guidance Documents Dating to 1975, N.Y. Times, Dec. 21, 2017.

${ }^{34}$ F. Scott Kieff, \& Anne Layne-Farrar, Incentive Effects from Different Approaches to Holdup Mitigation Surrounding Patent Remedies and Standard-Setting Organizations, 9 J. COMPETITION L. \& ECON. 1091, 1098-1100
} 
Antitrust Division, observing that " $[\mathrm{t}]$ he electoral cycle drives the political process that installs the Division's top officials into positions of ephemeral authority." 35 He attributes particularly short-sighted decisions by the Division to the "political cycle" and the fact that, when the impact of ill-advised policies eventually impact the economy, "[s]omeone else will be running the Antitrust Division". ${ }^{36}$ Admittedly, these authors were criticizing not Mr. Delrahim, but the Obama DOJ. Nevertheless, there is little to suggest that the Trump DOJ is any less motivated by political factors than the DOJ under prior administrations.

This being said, antitrust policy regarding standard-setting, and hold-up in particular, did not previously appear to run along party lines. In fact, many key DOJ position statements regarding hold-up, including those expressed in its 2006 and 2007 business review letters to VITA and IEEE, respectively, and the 2007 report on antitrust and IP that it produced jointly with the FTC, were developed during the Republican George W. Bush Administration. Each of these documents acknowledged the existence and potential anticompetitive effects of hold-up. At least in this area, the Obama DOJ did not appear to deviate significantly from the policies of prior administrations. As observed by FTC Commissioner Terrell McSweeny, the FTC and prior DOJ approach to combatting hold-up were based on "15 years of scholarship and bipartisan study" and should not lightly be discarded. ${ }^{37}$

\section{Aspirational Goals Only?}

AAG Delrahim's November speech caused considerable alarm across the technology and standardization industry and precipitated concerned letters from industry associations, major corporations and seventy-seven academics and former U.S. government officials. ${ }^{38}$ His message about potential DOJ enforcement in the area of standardization may have been viewed as encouraging to foreign antitrust authorities that have recently brought enforcement actions against U.S. firms, particularly Qualcomm. ${ }^{39}$

In response, Mr. Delrahim has scaled back his earlier statements. During an April 2018 conference in Brussels, he sought to distinguish the Antitrust Division's advocacy role from its enforcement role. As an advocate, he explained, the Division will "clarify what conditions are ideal" for competition, while "at the opposite end of the spectrum, what conduct might attract

(2013); see also F. Scott Kieff, Pragmatism, Perspectives, and Trade: AD/CVD, Patents, Antitrust as Mostly Private Law, 30 HARVARD J. L. \& TECH. 97, 119 (2017).

${ }^{35}$ Sidak, supra note 10 , at 72.

${ }^{36} \mathrm{Id}$.

${ }^{37}$ McSweeny, Holding the Line, supra note 26, at 1.

${ }^{38}$ See, e.g., Letter from Aces Health et al. to Asst. Atty. Gen. Makan Delrahim, Jan. 24, 2018; Letter from ACT The App Association et al. to Asst. Atty. Gen. Makan Delrahim, May 30, 2018; Letter from 77 former government enforcement officials and professors of law, economics, and business, to Asst. Atty. Gen. Makan Delrahim, May 17, 2018 (the author was a signatory to this letter). But see Barnett et al. Letter, supra note 27 (supporting policy change).

${ }^{39}$ Over the past several years, Qualcomm has been investigated and penalized for alleged unilateral violations of competition law by competition authorities in China, Taiwan, Korea, and the European Union. See Jorge L. Contreras, The Global Standards Wars: Patent and Competition Disputes in North America, Europe and Asia (working paper, Apr. 8, 2018), https://papers.ssrn.com/sol3/papers.cfm?abstract_id=3106090. As noted above, the FTC has also initiated litigation against Qualcomm. See note 25, supra, and accompanying text. 
enforcement scrutiny." 40 This distinction is important, as it clarifies that SDOs will not be required to conform to all of the Antitrust Division's aspirational goals, so long as they avoid what would be considered illegal collusion. Mr. Delrahim even went so far as to encourage industry-led SDOs to "experiment" and "be creative" with their patent policies. ${ }^{41}$ Perhaps this message should be heartening to SDOs. Even if their patent policies do not wholly align with the vision outlined by Mr. Delrahim, DOJ enforcement may not necessarily follow.

In the same speech, Mr. Delrahim also emphasized to foreign competition regulators that the conduct approved in DOJ business review letters (i.e., the 2015 IEEE letter) should be viewed as permitted (at the time), but certainly not as required. His concern seems to be that parties and other regulators might view the more controversial provisions of the IEEE policy (e.g., limiting the ability of SEP holders to seek injunctive relief) as a new floor on SDO conduct, rather than conduct permitted under the facts of the specific case. This point is well taken, though it is, in reality, nearly impossible to prevent the industry and, more importantly, the legal community from taking to heart the guidance offered in the DOJ's business review letters. Notably, the DOJ's MPEG-2, DVD and 3GPP business review letters have effectively shaped the law surrounding the structure of standards-based patent pools. As such, these letters are useful tools for delineating at least some boundaries on conduct that the Division considers to be permissible.

\section{What about Royalty-Free?}

Mr. Delrahim's November 2017 announcements also raise serious questions regarding the ability of SDOs to choose to release their standards on a royalty-free basis. Some of the most widely adopted standards in use today, including Bluetooth, USB, XML, TCP/IP and many more, are available for use without the payment of patent royalties. ${ }^{42}$ This broad and cost-free access has enabled significant market entry and innovation in a range of technology markets, including by small and medium enterprises. Yet as Mr. Delrahim explained, "[t]he Antitrust Division will ... be skeptical of rules that SSOs impose that appear designed specifically to shift bargaining leverage from IP creators to implementers". ${ }^{43}$

Clearly, policies that require royalty-free licensing of standards will be unpopular with firms that derive significant revenue from the monetization of patents. For example, when the Worldwide Web Consortium (W3C) adopted a royalty-free licensing policy for its Web-related standards in 2003, there were significant objections from large patent holders. Several major firms withdrew

\footnotetext{
${ }^{40}$ Asst. Atty. Gen. Antitrust Div., U.S. Dept. Justice, Makan Delrahim, The Long Run: Maximizing Innovation Incentives Through Advocacy and Enforcement-Remarks as Prepared for the LeadershIP Conference at 7-8, Apr. 10, 2018, https://www.justice.gov/opa/speech/file/1050956/download.

${ }^{41} I d$. at 8 .

${ }^{42}$ The firms responsible for the development of these standards have not made them available royalty-free out of philanthropic beneficence. Rather, these firms, which are often vertically integrated, have business models that favor the broad dissemination of interoperability standards to support their sale of products and services, and the broad availability of compatible devices. See, e.g., David J. Teece \& Edward F. Sherry, Standards Setting and Antitrust, 87 Minn. L. REv. 1913, 1954 (2003) (“'A] patent holder may be willing to license its patents royalty-free to all interested parties ... [T] his is most likely to occur ... when the patent holder will benefit from others' adoption of its patented technology as a standard because the patent holder has other complementary capabilities that will enable it to profit from its innovation in a manner other than collecting royalties.")

${ }^{43}$ Delrahim, Take it to the Limit, supra note 3, at 11.
} 
from the organization in protest. ${ }^{44}$ Yet W3C survived and thrived, most of the defecting members returned, and the Web today is deeply ingrained in the fabric of our global technology infrastructure. What would have happened had W3C proposed its 2003 policy amendment in the shadow of Mr. Delrahim's new skepticism of SDO rules that "that skew the bargain in the direction of implementers"? ${ }^{45}$

The author has recently posed this question to Mr. Delrahim and another official at the Antitrust Division. ${ }^{46}$ The responses have offered cold comfort to the effect that concerted behavior would need to be analyzed under prevailing antitrust rules, and that royalty-free arrangements might not be subject to enforcement if they are not directed toward the disadvantaging of patent holders. Yet the devil is clearly in the details, and further written clarification from the Antitrust Division in this important area would likely help to prevent the chilling of an important and innovative sector of the U.S. economy.

\section{The DOJ and the Courts}

In his April speech, Mr. Delrahim also sought to moderate his November 2017 criticism of the federal judiciary, namely Judge Richard Posner and the Court of Appeals for the Federal Circuit for their decisions in Apple v. Motorola. ${ }^{47}$ In November, Mr. Delrahim rebuked Judge Posner as the "badly mistaken" author of an "ill conceived" decision concerning the ability of SEP holders to seek injunctive relief. ${ }^{48}$ Whatever the merits of Mr. Delrahim's legal analysis, the tenor and very existence of his critique raise serious separation of powers concerns. The decisions in Apple v. Motorola were based not on antitrust law, but on an application of the Supreme Court's four-part equitable test for injunctive relief under eBay v. MercExchange. ${ }^{49}$ As the Federal Circuit emphasized, "The framework laid out by the Supreme Court in eBay, as interpreted by subsequent decisions of this court, provides ample strength and flexibility for addressing the unique aspects of FRAND committed patents and industry standards in general." 50

As such, the decisions of the trial and appellate courts in Apple v. Motorola were squarely within the province of the federal judiciary and, more importantly, well beyond the authority or competence of the DOJ Antitrust Division. In fact, even on matters of antitrust law, the DOJ does not make the law, but only enforces the law as it has been enacted by Congress and interpreted by the courts. Thus, Mr. Delrahim's sharp criticism of these decisions was not only ultra vires, but dishearteningly reminiscent of the current administration's public disdain for the federal judiciary.

\footnotetext{
${ }^{44}$ For a discussion of this episode see Jorge L. Contreras, A Tale of Two Networks: Patents, Standards and the Internet, 93 DENVER L. REV. 855, 876-78 (2016).

${ }^{45}$ Delrahim, Take it to the Limit, supra note 3, at 11.

${ }^{46}$ E.g., at the American National Standards Institute (ANSI) Intellectual Property Rights Policy Committee meeting, May 10-11, 2018; and the Federalist Society, Intellectual Property Practice Group and Regulatory Transparency Project Teleforum, Antitrust Regulation of the Use of Intellectual Property, July 17, 2018.

${ }^{47}$ Apple Inc. v. Motorola, Inc., 869 F. Supp. 2d 901, 913-15 (N.D. Ill. 2012), aff'd in part, rev'd in part, 757 F.3d 1286 (Fed. Cir. 2014).

${ }^{48}$ Delrahim, Take it to the Limit, supra note 3, at 12.

49547 U.S. 388 (2006).

50757 F.3d at 1332 (citing eBay, 547 U.S. at 391-94).
} 
Perhaps to allay these concerns, Mr. Delrahim explained in April that his comments regarding those judicial decisions were merely part of the DOJ's "advocacy" mission: an effort to share the Division's views "about what conditions will make the market most dynamic, innovative and competitive". ${ }^{51} \mathrm{He}$ also linked his critique to competitive conditions in the U.S., noting that "[a]s a defender of competitive markets, I am concerned that these patent law developments could have an unintended and harmful effect on dynamic competition by undermining important incentives to innovate, and ultimately, have a detrimental effect on U.S. consumers." ${ }^{52}$ As an experienced attorney and advocate in the area of competition policy, Mr. Delrahim is certainly entitled to his own opinions regarding the best means for improving competitive conditions in the U.S. As the leader of the DOJ Antitrust Division, however, this episode suggests that it would be preferable if he limited his public statements made in this capacity to the application and enforcement of the antitrust laws.

\section{What Will the Future Hold?}

Mr. Delrahim's comments about the courts highlights an important point about agency policy. While the DOJ may determine what cases it wishes to litigate and on what theories it wishes to pursue them, ultimately it is the courts that will decide what conduct is or is not permitted under the antitrust laws. ${ }^{53}$ It is also worth remembering that the DOJ is but one of two antitrust enforcement agencies in the U.S., and the one that has taken a back seat in the enforcement arena over the past two decades. And while the DOJ and FTC have in recent memory been aligned on issues relating to patents and standards, a divergence of views, much like a circuit split in the courts, may actually push the judicial system to provide more definitive answers to some of the difficult questions affecting the area of standard setting. It is also worth recalling that the DOJ's newly permissive position toward unilateral conduct is out of step with competition agencies around the world. ${ }^{54}$ Thus, international comity may also nudge the DOJ back toward a more centrist position. Thus, while the DOJ's new approach toward patents and standards may cause SDOs concern in the short term, it is hoped that the threat of antitrust enforcement will not seriously chill the important work coordinated by SDOs in the United States.

\footnotetext{
${ }^{51}$ Delrahim, The Long Run, supra note 40, at 2.

52 Id. at 3 .

${ }^{53}$ The Antitrust Division today should be all too aware of this fact, given its recent setback in United States $v$. AT\& T Inc., Case No. 1:17cv-02511-RJL (D.D.C. Jun. 12, 2018) (currently under appeal). The FTC has also suffered its share of litigation reversals, notably in Rambus, Inc. v. FTC, 522 F.3d 456 (D.C. Cir. 2008).

${ }^{54}$ See note 39, supra.
} 